THURSDAY, AUGUST I3, I89ז.

\section{THE INTERNATIONAL CONGRESS OF} HYGIENE ANI) DEMOGRAPHY.

$\mathrm{T}^{\mathrm{H}}$ HIS Congress, the work of which we refer to in another column, which is now in full swing, promises to be one of the most important meetings of the kind that has ever been held, not only in point of numbers, but also on account of the far-reaching results likely to accrue from it.

A remarkable combination of circumstances has contributed to its success. In the first place, it is beld in the country which has been the pioneer of sanitary work; and then it has the patronage of Her Majesty the Queen, who, it is well known, takes a deep personal interest in its success; and has as its President, not merely in an honorary sense, His Royal Highness the Prince of Wales, who presided and gave an admirable address of welcome at the splendid opening meeting on Monday in St. James's Hall.

This is the seventh of a series of similar Congresses which have been held in various parts of Europe, and one is tempted to ask what they have accomplished. An answer is at once forthcoming. The all-important question of quarantine has been discussed at several of these Congresses. Not to go farther back than the Congress at The Hague, held in $\mathbf{1 8 8 4}$, we find, from the excellent reporis issued by the editor; of the Lancet, that then the feeling in Europe was so strongly opposed to the English views as to the inutility of quarantine and the superiority of our method of medical inspection, that the English delegate was not even allowed to explain the English position in the matter, but the discussion was peremptorily closed, on the ground that the subject had been sufficiently discussed on the previous day. At the Vienna Congress, in I 887, quarantine was again discussed under the subject of cholera; and the veteran Pettenkoffer told the members of various countries present that they had only to follow the example of England, in looking after their systems of water-supply and sewerage, and in isolating cases of infectious disease, and they would be no more afraid of cholera than the English were, even with their continual communication with India, the home of that disease, and would have no need of quarantine, with all its vexatious and ineffective restrictions, and all its unnecessary interference with commerce. Now, Continental opinion is almost entirely on our side, and it is doubtful whether there will be any serious discussion on the matter.

But there are many other subjects with which the Congress will interest itself, and about which such an interchange of views as can only be obtained at an International Congress must be of the greatest benefit. The whole subject of bacteriology has grown up within the last few years, and one of the most important and best attended Sections of the Congress is devoted to it, many of the highest authorities on this subject having been attracted here to take part in the discussion under the presidency of Sir Joseph Lister. The abnormal prevalence of diphtheria, not only in our own large towns,

$$
\text { NO. I I } 37 \text {, VOL. 44] }
$$

but also in those of other parts of Europe and in America, in many cities of which, especially in the Western States of North America, it has become a veritable plague, is likely to occasion an important discussion in Section I., under the presidency of Sir Joseph Fayrer. The mention of his name leads us to observe that India is well to the front in this Congress, for not only have a number of delegates been sent by her Provinces and Native States, but they have also largely contributed to the funds of the Congress.

Influenza, too, our new plague, about which we seem to know so little, might be discussed, as to its mode of spread and methods of prevention, with great advantage at a meeting where so much experience from all parts of the world is focussed.

An especial feature in this Congress is, as might be expected in England, the prominence which is given to engineering and architecture in connection with hygiene, there being two separate Sections devoted to these branches of the subject.

The division of demography, too, which has been so much talked about on account of its name, which was up to the present time unfamiliar to English ears, and which has been defined by some wag as "the art of drawing the public," has attracted, under the presidency of Mr. Francis Galton, many of the most eminent statisticians of Europe, whose discussions cannot fail to promote the attainment of more uniformity in the methods of statistical inquiries.

This is an age of Congresses, and if they are, as it is universally agreed that they are, of any usz at all, it is self-evident that the most useful and the most important are the international ones.

\section{A LIFE OF DARWIN.}

Charles Darwin: His Life and Work. By Charles Frederick Holder. (New York and London: G. P. Putnam's Sons, 1891.)

RETWEEN the voluminous "Life and Letters" of his father, by Prof. Francis Darwin, and the brief epitome of Darwin's work, by Mr. G. T. Bettany, published in 1887 in the "Great Writers" series, there has hitherto been a gap which has only been partially filled by such books as Grant Allen's "Charles Darwin" in the series of "English Worthies." In the first of the works mentioned, our great naturalist is chiefly allowed to speak for himself, while in the second we have a digest of his scientific achievements. Although it has been generally considered that the life of Darwin from the time of the return of the Beagle was too uneventful to make an interesting biography, we bave always been of opinion that there existed sufficient material for a popular "Life" of the very greatest interest provided that this material could be skilfully and judiciously worked up. The work under notice supplies this want, and American and English readers are now provided with a biography which is both entertaining and accurate.

Of course the material out of which Mr. Holder has woven his story is for the most part to be found in Darwin's own writings, or in the "Life and Letters," and readers who turn to the pages of this book with the hope of finding new matter may be disappointed. But the very circumstance that out of the familiar records of the 